\title{
POLITICAL PRAXIS, SOCIAL ANALYSIS AND WESTERN MODERNIZATION: A THEORETICAL-POLITICAL ROUTE FOR CRITICAL SOCIAL THEORY
}

\author{
Leno Francisco Danner ${ }^{1}$ \\ Universidade Federal de Rondônia (UNIR) \\ (iD) http://orcid.org/0000-0002-2332-3182 \\ E-mail: leno_danner@yahoo.com.br \\ Fernando Danner ${ }^{2}$ \\ Universidade Federal de Rondônia (UNIR) \\ (i) http://orcid.org/0000-0002-4541-1204 \\ E-mail: fernando.danner@gmail.com
}

\begin{abstract}
:
This paper criticizes the emphasis placed by contemporary social theory and political philosophy on institutionalism as the basis for the understanding, legitimation and changing of institutions, or social systems, and society as a whole. The more impactful characteristic of institutionalism is its technical-logical structuring, based on an impartial, neutral and formal proceduralism that autonomizes social systems in relation to political praxis and social normativity, depoliticizing these social systems. Here, they are no longer depoliticized, but assume political centrality as the fundamental social subjects of the legitimation and evolution of institutions and society. The paper's central argument is that it is necessary to re-politicize the institutions and the social subjects or social classes in order to ground and streamline a direct political praxis and the civil society's social-political subjects as the basis for framing and legitimizing the current process of Western modernization. Recovering the politicity and the carnality of institutions, of social classes and of the evolution of society, is the fundamental task for a contemporary critical social theory that faces the strong institutionalism based on systemic theory. Such politicization is the unforgettable teaching of Karl Marx and Erich Fromm: the institutions have political content and political subjects, they are the result of social struggles for hegemony between opposed social classes which are political. Now, such politicity-carnality must be unveiled and used for an emancipatory democratic political praxis as the route for social analysis and political change, in opposition to the technical-logical understanding both of the institutions and of the social subjects.
\end{abstract}

KEYWORDS: Critical Social Theory; Institutions; Politicity-Carnality; Politics; Social Evolution.

\section{PRÁXIS POLÍTICA, ANÁLISE SOCIAL E MODERNIZAÇÃO OCIDENTAL: UM CAMINHO TEÓRICO-POLÍTICO PARA A TEORIA SOCIAL CRÍTICA}

\begin{abstract}
RESUMO:
o artigo critica a ênfase, por parte da teoria social e da filosofia política contemporâneas, no institucionalismo enquanto base para a compreensão, legitimação e transformação seja das próprias instituições ou sistemas sociais, seja da sociedade como um todo. A mais impactante característica do institucionalismo consiste em sua estruturação lógico-técnica, baseada em um procedimentalismo que é imparcial, neutro e formal, e que, por isso, autonomiza os sistemas sociais em relação à práxis política e à normatividade social, despolitizando-os. Aqui, eles se tornam não apenas estruturas despolitizadas, mas também ganham centralidade como os sujeitos políticos fundamentais da legitimação e da evolução tanto das instituições quanto da sociedade de um modo mais geral. $\mathrm{O}$ argumento central do artigo consiste em que é necessário politizar de novo e fortemente as instituições e os sujeitos sociais ou classes sociais, de modo a fundar e a dinamizar uma práxis política direta, assim como os sujeitos sociopolíticos desde a sociedade civil, como a base para o enquadramento e a legitimação do atual processo de modernização ocidental. Retomar a politicidade, a carnalidade das instituições, das classes sociais e da evolução da sociedade é a tarefa fundamental para uma teoria social crítica que enfrenta o institucionalismo forte fundado na teoria sistêmica. Uma tal politização, na verdade, é o inesquecível ensinamento de Karl Marx e de Erich Fromm: as instituições possuem um conteúdo político e sujeitos políticos, elas são o resultado de lutas sociais por hegemonia entre classes sociais contrapostas que são fundamentalmente políticas. Ora, esta politicidade-carnalidade deve ser desvelada e usada por uma práxis política democrática emancipatória como a rota para a análise social e para a mudança política, em oposição à compreensão técnico-lógica seja das instituições, seja dos sujeitos sociais.
\end{abstract}

PALAVRAS-CHAVE: Teoria Social Crítica; Instituições; Politicidade-Carnalidade; Política; Evolução Social.

\footnotetext{
${ }^{1}$ Doutor em Filosofia pela Pontifícia Universidade Católica do Rio grande do Sul (PUCRS), Porto Alegre - RS, Brasil. Professor de Filosofia da Universidade Federal de Rondônia (UNIR), Porto Velho - RO, Brasil.

${ }^{2}$ Doutor em Filosofia pela Pontifícia Universidade Católica do Rio grande do Sul (PUCRS), Porto Alegre - RS, Brasil. Professor de Filosofia da Universidade Federal de Rondônia (UNIR), Porto Velho - RO, Brasil.
}

DANNER, Leno Francisco; DANNER, Fernando. Political Praxis, Social Analysis and Western Modernization: A Theoretical-Political Route for Critical Social Theory. Griot : Revista de Filosofia, Amargosa - BA, v.20, n.2, p.154-173, junho, 2020. 


\section{Introduction}

The social theory of the $20^{\text {th }}$ century, starting with Max Weber, going through Talcott Parsons and coming to Niklas Luhmann, Jürgen Habermas and Anthony Giddens, has assumed an institutionalist or systemic understanding of the constitution, grounding and evolution of institutions as well as of the societal constitution and dynamic as a whole, in the sense that both the social evolution would be streamlined basically from the institutions as social-political subjects, and these social institutions would be characterized as a technical-logical set of impartial, neutral and formal procedures, codes and legal staff from which the very institutions and the societal dynamic would be defined, legitimized and streamlined over time. The same happens with many contemporary political theories, especially those of liberal orientation, like conservative liberalism (such as the ideas of Friedrich August von Hayek and Robert Nozick) and the New Left (Rawls, and the above mentioned Habermas and Giddens), that assume an institutionalist role regarding both institutional praxis and the evolution of society. This means that contemporary societies have the institutions as their main basis, that is, technical-logical institutions as sets of impartial, neutral and formal dynamics, procedures, codes and selfauthorized elites that become non-political and non-normative structures and subjects of institutional and societal legitimation and evolution. Political praxis and social normativitywhich were the very basic goals of social theory in their attempt to understand, frame and change the pathologies and alienations of Western modernization-are important arenas and instruments from which contemporary democratic politics is formulated, grounded and streamlined, but they are living — as they must live - today side by side with the fundamental technical-logical arena, proceduralism and legal subject which are the very institutions or social systems.

In this article, I argue that the institutionalism assumed by contemporary social theories and political philosophies as the basis for understanding, grounding and changing the current process of Western modernization leads to the depoliticization of social-political subjects or social-political classes due to the affirmation and strong emphasis on the technical-logical institutions or social systems as constituting the arena, procedures and legal subjects of the institutional-societal constitution, legitimation and evolution. Such strong institutionalism leads also to the institutions' self-referentiality, self-subsistence and closure regarding the political subjects of civil society, delegitimizing a direct democratic political praxis based on social normativity within the same social systems. As a consequence, institutions acquire a nonpolitical and non-normative constitution, legitimation and evolution, autonomizing themselves in relation to civil society, to social movements and citizen initiatives, political praxis and social normativity. At the same time, technical-logical institutions can perform a correlative theoretical-political movement: (a) their technical-logical constitution-by transforming them into self-referential, self-subsisting and autonomous instances and subjects regarding the political-normative classes and struggles of civil society-leads to institutional closure and independence in political-normative terms, so they cannot be framed and changed from political-normative principles, practices and subjects, but only from the technical-logical proceduralism, codes and legal staff; (b) such technical-logical institutional constitution and grounding not only requires independence in relation to politics and social normativity, but also imposes constraints and technical-logical limitations on civil society and on democratic politics in order to minimize the political-normative impact and amplitude of social struggles, political praxis and social classes.

The central argument of this article is that institutionalism, based on a technical-logical understanding of social systems - although it tries to conciliate the technical-logical functioning 
and programming of institutions with the normative-political constitution of civil society-, depoliticizes institutional and societal constitution as social subjects. Here, a social theory and a political praxis based on systemic theory cannot achieve an emancipatory dimension, because it is limited, defined and delegitimized by the social systems' technical-logical constitution, legitimation and evolution. Thus, a critical social theory for the $21^{\text {st }}$ century, to face strong institutionalism as the basis for understanding the current process of Western modernization, must re-politicize both the understanding of social systems and social subjects or social classes. Such politicization of institutions and social subjects is necessary and urgent in order to oppose conservative liberalism, which is based on the technical-logical, depoliticized comprehension of social systems, and offers a theoretical-political alternative to it. Conservative liberalism is theoretically and politically hegemonic nowadays as the option par excellence for the resolution of the current national and international social-economic crisis. Indeed, such politicization is pointed out both by the Marxist social theory (see MARX, 2013; MARX \& ENGELS, 2008) and by psychoanalysis and social psychology as the fundamental theoretical-political basis to the understanding and emancipation of both the institutions and the social classes and individuals, as suggested by Erich Fromm in many of his works-politicity as institutional carnality, as the carnality of praxis (cf.: FROMM, 1970, 2009). Here, class consciousness and belonging, as social struggles, define the institutional perspective and social evolution, which means that there is not a technical-logical institution or a depoliticized social class on which institution and society are grounded and streamlined. Likewise, institutional and societal carnality is constituted by the opposition, the social-political struggles for hegemony between opposed social classes-this is the starting point to understand the process of Western modernization and face the current strong institutionalism in politics, which weakens the politicity of practical life, depoliticizing the institutional constitution, legitimation and evolution and delegitimizing the very politicity of the social subjects and their social-political struggles for hegemony.

\section{Critical Social Theory and the Western Modernization}

One of the most important characteristics of the social theory of the $20^{\text {th }}$ century is the substitution of political subjects or social classes with institutions or social systems or structures as the theoretical-political basis for social analysis and political action-contemporary political theorists such as John Rawls, Jürgen Habermas and Anthony Giddens follow this path, by refusing to assume a political understanding of social subjects-whose politicity is not possible to be thematized or attributed, according to them, due to the fact that such social subjects are very individualized, losing their class consciousness and belonging — and by using the notion of institution or social system as an objective set of rules, procedures and legal staff which streamlines its specific social field from an impartial, neutral and formal dynamics of technical and logical character, non-normative and non-political (see RAWLS, 2003; HABERMAS, 2012a, 2012b, 2003a, 2003b; GIDDENS, 1996, 2000, 2001). Firstly, therefore, the social theory of the $20^{\text {th }}$ century gives absolute priority to the technical-logical institutions or social systems, and not to social classes, which are political subjects of social evolution: the social evolution is a matter of institutionalism, as performed from institutionalism. What is the reason for that? The social theory of the $20^{\text {th }}$ century is based on a notion of Western modernization characterized as a process of systemic institutional self-differentiation, self-referentiality and self-subsistence in which technical-logical institutions centralize and monopolize specific social fields, becoming the very fields that they represent and transforming them into non-political and non-normative instances or structures. This notion of Western modernization, widely and strongly assumed by 
the social theorists of the $20^{\text {th }}$ century (for example, Max Weber, Talcott Parsons, Niklas Luhmann, Jürgen Habermas and Anthony Giddens), see institutions or social systems as the basic core and subject of institutional and societal constitution, legitimation and evolution, minimizing and weakening the politicity of the class conditions, of the differences between social classes, the very conflictive sense of the struggles between these social subjects or classes as the platform from which institutions and societal dynamics are streamlined and defined over time (see WEBER, 1984; PARSONS, 2010a, 2010b; LUHMANN, 2006; HABERMAS, 2012a, 2012b; GIDDENS, 1996, 2000, 2001).

What does a social system or institution actually consist of? It consists of, as said above, a set of impartial, neutral and formal procedures, rules, practices and legal staff which are basically technical-logical structures and subjects, non-political and non-normative instances that centralize and monopolize each and every field of society. That is the conclusion of $20^{\text {th }}$ century social theory in its studies about the emergence and consolidation of Western modernization, that is, European modernization characterized by the correlative consolidation of different social systems such as the capitalist market and the bureaucratic-administrative State, in addition to other institutions such as science and the arts, and of a universalistic culture and consciousness marked by the separation between nature, culture or society and individuality as the basis of the normative paradigm of modernity. The most important feature of the theories of modernity developed and assumed in the $20^{\text {th }}$ century is the understanding that Western modernization (the societal, institutional and cultural process of evolution which has differentiated us - the sons of Europe-in relation to traditional societies) signifies a process in which institutions or social systems emerge as closed, self-referential and self-subsisting technical-logical structures that centralize and monopolize each one of the social spheres, becoming the very social sphere that they represent. Contrarily to traditional societies, which are a totality defined by a single principle of social integration (religion, nature, class belonging, politics etc.), European modernity is divided into many different and particular social fields or institutions, each of them constituted and legitimized from a specific kind of technical-logical principle (money and power in institutional terms, for example), which is also true in relation to social normativity (in cultural terms) (see HABERMAS, 2012a, p. 09-11; 2012a, p. 278; 2002a, p. 01-08, p. 484-517; GIDDENS, 1996, p. 95, p. 175; 2001, p. 123-134). The basic theoreticalpolitical consequence that arises from here is the fact that the social dynamics and status quo are defined in the first place from the social systems' movement, dynamics and specificity, and not from the social struggles between opposed social subjects or classes-which make them (social dynamic and status quo) a technical-logical matter and consequence.

Indeed, modern societies must operate henceforward based on the fact that social systems or institutions are not always political and normative, but fundamentally technicallogical structures, closed and self-referential technical-logical instances conducted and managed by a legal staff based on scientific-technical objective rules, practices and procedures. Likewise, modern societies must operate from now on with the fact that society is no longer a totality imbricated in its parts, characterized and permeated from one corner to another by the political-normative constitution and defined by political praxis. From now on, therefore, the theoretical analysis and political changing of modern societies must take seriously and start from the fact that these modern societies are divided into non-political and non-normative social systems or institutions, which means that the understanding and the transformation of these modern societies is not always a political matter or a political praxis based on social normativity and performed by political social subjects or classes, but from the internal rules, practices, procedures and legal staff of the institutions themselves (see LUHMANN, 2006, p. 40-88; HABERMAS, 1997, p. 163-163; 2003a, p. 61; GIDDENS, 1996, p. 93-102; 2000, p. 38-43; 2001,

DANNER, Leno Francisco; DANNER, Fernando. Political Praxis, Social Analysis and Western Modernization: A Theoretical-Political Route for Critical Social Theory. Griot : Revista de Filosofia, Amargosa - BA, v.20, n.2, p.154-173, junho, 2020. 
p. 144-154). In talking about systemic institutional pathologies, such as market inequalities and State's technocracy and bureaucratization, we refer to problems that must be tackled firstly and basically from within the institutions' internal dynamics, procedures and legal staff, because their internal constitution and legitimation are technical-logical, scientific, non-political and non-normative structures. Then, the discussion about institutional problems must take into account the fact that their resolution is not firstly a political-normative praxis and matter, but a technical-logical action, a depoliticized practice. Systemic institutions are technical-logical institutions; their procedures, codes and legal staff are technical-logical instances and subjects which work from a depoliticized and non-normative constitution, legitimation and evolution.

The fundamental theoretical standpoint shared by the sociology of the $20^{\text {th }}$ century, therefore, is that institutions or social systems are a set of technical-logical procedures with nonpolitical and non-normative dynamics, functioning and programming. Such technical-logical institutions (money and bureaucratic power exemplarily represent these technical-logical institutional principles and procedures, at least in the liberal tradition) are streamlined and managed from impartial, neutral and formal proceduralism and codes centralized in and legitimized by technical-scientific staff and institutional elites, since each social system, from its self-referentiality and self-subsistence, its technical-logical structuration and grounding, has an internal legal staff and institutional elite that act from an objective (neutral, impartial and formal) practice based on scientific-technical rules and procedures-the so-called instrumental reason of Weber and the Frankfurt School. This leads to the strong depoliticization of social systems, by technicizing them, by transforming them in closed, self-referential and selfsubsisting institutions individualized and separated from the social sphere in which they are rooted. Social systems' closure, self-referentiality and self-subsistence are made possible by their technical-logical constitution and legitimation which differentiate and at the same time autonomize them in relation to the normative constitution and legitimation of culture. In this sense, the systemic understanding of the process of Western modernization, in the moment that it conceives of modern institutions as technical-logical structures with a technical-logical functioning and programming managed by a technical-logical legal staff, depoliticizes these institutions (bureaucratic power and money) and their subjects, establishing a barrier between the essentially technical-logical institutions and the society's normative constitution, which cannot be crossed or broken, especially in terms of the social systems' functioning and programming (see HABERMAS, 2003a, p. 61; 2012b, p. 216; GIDDENS, 2000, p. 54-56; 2001, p. 78).

This is a very pungent problem to a critical social theory that intends to protect and to foment the social world in relation to the pathologies of social systems. Habermas and Giddens, for example, are aware of that problem, they are conscious that a pure systemic theory directly leads to the institutional closure and depoliticization of democratic political praxis, because it conceives of social systems or institutions, as said above, as technical-logical structures which have a non-political and non-normative constitution, legitimation and evolution. So, their social theories search for an option to a pure systemic theory that can at the same time seriously approach the systemic theory for the study of Western modernization and offer a notion of social normativity as a counterpoint to the technical-logical institutional constitution and grounding proposed by systemic theory, allowing a model of democratic political praxis based on social normativity which confronts and frames the pure and simple technical-logical constitution and grounding of social systems. Therefore, on the one hand, Habermas and Giddens believe that the systemic theory is the basic theoretical approach for understanding modern institutions, such as the capitalist market and the bureaucratic-administrative State, which are, for these intellectuals, technical-logical structures. On the other hand, they intend to 
reconstruct a model of European cultural modernity that enables a binding notion of social normativity which not only constitutes the vital sphere of the lifeworld, but also-and for this reason-serves as a political standpoint from which the systemic institutions, as systemic pathologies, can be analyzed and framed. In other words, a model of social normativity allows the mensuration of institutional dynamics and pathologies in the sphere of the lifeworld to a critical social theory and a democratic political praxis whenever each of these social systems (and particularly State and market, bureaucratic power and money) invades and destroys the society's normative constitution and legitimation (see HABERMAS, 2012a, 2002a, 2002b, 1997; GIDDENS, 2000, 2001; HONNETH, 2007; FORST, 2010).

Therefore, the main argument or theoretical strategy employed by Habermas and Giddens in order to avoid the depoliticization of social systems by a pure systemic theory is that a modern society is divided into different spheres, each one of them with a specific constitution and legitimation. Habermas's division of Western modernization into systems (capitalist market and bureaucratic-administrative State) and lifeworld exemplifies such understanding of Western modernization as a multiple and differentiated process of institutional and societal evolution, programming and functioning. Now, such differentiation into social systems and culture, into technical-logical instances and social normativity enables the correlation between technicallogical analysis and action and normative-political analysis and praxis. And how can this be accomplished? Firstly, there are three specific principles of social dynamics and integration in modern societies, namely bureaucratic power, whose goal is the centralization of the administration of society as the central management of the use of rightful violence by the State; money, whose goal is the viability of economic activities and market relations from their monetization, intermediating work and commercial relations from impersonal instruments and actors based on the pursuit of profit and the exploration of work; and social normativity, whose aim is the intermediation of social relations with the use of moral-political practices, claims and foundations, and subjects as well. Bureaucratic power and money are technical-logical instances, structures and instruments, as they are the basic principles of technical-logical economic and political institutions. Social normativity is a moral-political principle and it is part of a moral-political world which is constituted and evolves over time from a moral-political praxis, justification and constitution. Secondly, each one of these social systems, as the lifeworld itself, is a particular social sphere with their own dynamics, codes, practices and subjects. They work well over time by such a particular constitution, which means that their private constitution and grounding cannot be substituted with alien principles, practices and subjects nor violated by other social logics and subjects, because that would disrupt the social systems' or the lifeworld's internal specificity, constitution, legitimation and evolution. The basis of the State's constitution, legitimation and evolution is the bureaucratic power; the basis of the market's constitution, legitimation and evolution is money; and the basis of the lifeworld's constitution, legitimation and evolution is morality and politics. This is the specificity of Western modernization in relation to traditional societies' totalizing and unidimensional constitution, legitimation and evolution, and that must be taken seriously by a social theory that intends to ground both a theoretical analysis of modern societies and a democratic political praxis for contemporary societies based on the process of Western modernization (see HABERMAS, 2012a, p. 140-141).

How are systemic analysis and political-normative praxis conciliated? How do they relate to each other? And how do the systems and the lifeworld connect to each other? According to Habermas and Giddens, it is necessary to distinguish the theoretical analysis regarding the social systems and the political praxis from civil society to political institutions. This differentiation means that social systems have an internal constitution and legitimation 
which is characterized by a technical-logical proceduralism and managed by a scientific legal staff, whereas civil society's political praxis is a spontaneous and moral action based on a normative understanding of both the constitution and grounding of civil society and of the moral structuration of institutions. However, these ideas just do not stand. Indeed, systemic institutions assume a normative orientation and political dynamics only in an indirect way, since they need to create normative social and individual expectations, as they influence the political structuration of both the society and the institutions. However, first of all, social systems, as technical-logical instances based on and streamlined by technical-logical procedures, codes and legal staff, are non-normative and non-political instances and subjects, which means that their internal constitution is technical and logical, managed by a scientific legal staff. Here, social normativity and political praxis can frame and influence the functioning and programming of social systems only indirectly. These technical-logical constitution and proceduralism cannot be directly substituted with normative-political principles, since this would disrupt the internal constitution, legitimation and evolution of social systems-a very typical characteristic and specificity of Western modernization. Likewise, a scientific legal staff that works based on scientific methodology, codes and practices cannot be directly substituted with a spontaneous political praxis provided by social movements and citizen initiatives with no scientific knowledge about the technical-logical constitution and grounding of social systems. As said above, this differentiation between social systems and lifeworld, bureaucratic power and money in relation to social normativity and politics is necessary both to the understanding of Western modernization and to the grounding of a theoretical analysis and political praxis to contemporary societies.

Bureaucratic power, money and social normativity have a specificity or singularity which must be taken seriously by theoretical analysis and political praxis. Each of these social spheres works basically and firstly from a kind of self-referentiality that is the parameter from which both the social analysis and the political praxis can be thought of and performed. On the other hand, there is a zone of contact which is essentially political-normative, which allows the recovery and the renewal of a normative foundation and of a political praxis for Western modernization, avoiding a pure and simple centrality and technicality of the internal dynamics of social systems, that is, avoiding the social systems' pure technical-logical constitution, grounding and evolution. State's bureaucratic-administrative power needs political-legal obedience and cooperation of the mass of citizens and social groups; capitalist market's money needs workers and consumers as the condition to its stability and functioning, as well as the condition for profit; social normativity needs political and economic institutions, because its basic material necessities and political management is performed from institutional constitution and action. Bureaucratic-administrative power and money, therefore, requires the lifeworld, as they impact the lifeworld's constitution and evolution. Likewise, the lifeworld requires the State's management and the market's material organization of economic production (see HABERMAS, 2012b, p. 272-273; GIDDENS, 2000, p. 55; 2001, p. 50). In addition, the theories of modernity proposed by Weber, Habermas and Giddens conceive of the emergence and consolidation of the process of Western modernization as a cultural transformation that enabled the systemic institutional differentiation and autonomy both between each of these social systems regarding the others and in relation to the normative constitution of the lifeworld. This means that cultural modernity (the rationalization of the European society, its separation between nature, culture or society and individuality as the basis of the constitution, evolution and specificity of modernity) enabled the economic-political modernity (capitalist market and bureaucratic-administrative State). So the correlation between the States' power, capitalist 
market's money and social normativity is also a theoretical-political key for understanding and framing Western modernization (see HABERMAS, 2012a, p. 588; 2002b, p. 335-336).

All this entails the possibility of an intermediation between social systems and lifeworld from a political-normative praxis, by the fact that the process of Western modernization is not a pure systemic institutional constitution and evolution. The sociological reconstruction and the history of Western modernization find within modernity a normative notion of culture that was and is the basis of Western modernization as a whole! In both cases-European cultural modernity as condition to economic-political modernity and the mutual dependence between State's power, capitalist market's money and lifeworld's social normativity-, the political praxis based on social normativity has a definite right in terms of political-economic framing and orientation: social systems must pay attention to and obey the lifeworld's normativepolitical constitution, legitimation, claims and action. Here the Habermasian affirmation that the process of Western modernization is a societal evolutionary movement characterized by the correlation, dependence and at the same time differentiation between social systems and the lifeworld appears and acquires sense insofar as such process of Western modernization is marked by the consolidation of technical-logical institutions or social systems, which are self-referential, self-subsisting and autonomous in relation to the lifeworld as a normative sphere, within (however self-referential, self-subsisting and autonomous!) the lifeworld itself! In addition, the dialectics between social systems and lifeworld also becomes evident, that is, the contradictions that are found in the development of each one of these principles of societal, institutional and vital organization (bureaucratic power, money and social normativity), as the mutual correlations between them which are characterized by interdependent normative claims and a political action that links all of them in a common praxis. In other words, the contradictions of Western modernization have sense due to the fact that the social systems have developed and continue to develop from the lifeworld's rationalization, but over time they consume and reify the lifeworld's normative constitution, generating social and individual pathologies (bureaucratization, poverty, violence, social inequalities, etc.); on the other hand, they also make sense due to the fact that the social systems developed within the lifeworld and from the lifeworld's rationalization, as well as due to the fact that social systems need the lifeworld's normative constitution to enable the grounding of both normative claims and of a political praxis directed to the framing and the transformation of the functioning and programming of social systems (see HABERMAS, 2012a, p. 383-384, p. 685; GIDDENS, 2001, p. 46-48).

Now, from this theoretical-political standpoint-the correlation and the dialectics between technical-logical social systems and the normative lifeworld-, the process of Western modernization acquires dynamicity, specificity and even dramaticity: on the one hand, there are the particularized, self-referential and self-subsisting principles of institutional constitution, legitimation and evolution, which are technical-logical, non-political and non-normative institutions and principles (in the Marxist terminology, exchange values; in liberal terminology, laissez-faire in terms of market organization and a Night-Watchman State in political terms); on the other hand, there is a lifeworld basically constituted by social normativity, by use values, which is the condition of systemic constitution and evolution as well as the material for the functioning and development of the institution, and finally which suffers the impact of the systemic institutional over-development over time-let us remember that the social and individual pathologies are caused by the social systems' technical-logical constitution which invades and colonizes the lifeworld, substituting its normative constitution with a technicallogical constitution, or at least imposing a technical-logical constitution on a normative sphere. What kind of contact and relationship is possible from here? Habermas and Giddens say that only an indirect political-normative intervention into social systems is possible, due to the fact 
that these social systems are technical-logical institutions and have a technical-logical functioning and programming that cannot be substituted with political praxis and social normativity, as such technical-logical orientation cannot be intervened in from the outside by political-normative praxis, principles and actors (see HABERMAS, 2012a, p. 355-365; 2003b, p. 147-148; GIDDENS, 2000, p. 12-15, p. 46, p. 62). Basically, therefore, a direct democratic political praxis grounded on social normativity cannot frame and orientate the social systems' constitution, legitimation and evolution, as much as social-political subjects cannot substitute for the institutions' internal proceduralism, principles and legal staff. The social systems' subjects are not political-normative, but technical-logical, since these institutions or social systems are technical-logical structures, differentiated and autonomous in relation to social normativity. It is from here that the political praxis and the social-political subjects must be thought of and streamlined, as it is from here that democratic political praxis must start.

\section{Who is the Social Subject of Politics and of the Institutions?}

In order to understand about the political subjects of social evolution as discussed in Habermas's and Giddens's theories of modernity, two important theoretical-political assumptions need to be considered, namely the notion of social system or institution as a basic characteristic of the process of Western modernization and the concept of complex society as the basis for understanding contemporary democratic societies. These two ideas define what democratic political praxis can and cannot do in terms of contact and influence between social systems and lifeworld, juridical-political institutions and civil society, institution's legal staff (political parties, courts, technicians etc.) and social movements and citizen initiatives. A social system or institution is a set of formal, impartial and neutral procedures, practices, codes and legal staff centralizing and monopolizing from a technical-logical management and constitution the legitimation and the evolution of its specific social field, becoming, as a consequence, the very social field it represents. A social system or institution, therefore, is a social-political subject, insofar as it is the social field streamlined and defined by it. As a social-political subject which centralizes and monopolizes the constitution, the legitimation and the evolution of its particular social field, the social system or institution is the basic political subject, arena and procedure of its specific social field (see HABERMAS, 2003a, p. 17-18; 2003b, p. 104; GIDDENS, p. 2000, p. 109-110). Therefore, it should first be taken into account, with regard to Habermas's and Giddens's theories of modernity, that each institution or social system becomes the fundamental political subject of its own social field - economy, from a scientific (objective, impartial, neutral and procedural methodology and action) standpoint, becoming the economic field itself, centralizing its constitution, legitimation and evolution over time, beyond any other institution or social-political subject, establishing economic principles as the fundamental structure of the economic field, beyond any other principle (the same happens with the State, which is characterized by the bureaucratic-administrative power, something very different from economic principles and social normativity).

The fact that the social system or institution is a political subject means, firstly, as said above, that it is the sole responsible for its particular social field or, at least, it is the basic arena, procedure and political subject of constitution, legitimation and evolution of its social field. Any social change and political praxis must take that into account. It means, therefore, that each institution centralizes and monopolizes the constitution, the legitimation and the evolution of its social field. Secondly, as was also remarked before, a social system or institution is a set of impartial, neutral and formal procedures, practices, codes and legal staff, a technical-logical structure streamlined by technical-logical practices and codes. Now, as a technical-logical 
structure, its constitution, legitimation and evolution is based on a technical-logical action performed by a legal staff from inside the institutions. Two important theoretical-political points stand out: (a) the constitution, legitimation and evolution of social systems are internal actions and matters, performed and managed by an internal legal staff which comprehends the technical-logical constitution, legitimation and evolution of the institutions, acting from technical-logical principles and practices; as a consequence, (b) institutions become highly independent, self-subsisting and self-referential regarding the social context from which they emerge, in which they are located, opposing it and becoming very differentiated in relation to it. So, a technical-logical structure admits only technical-logical procedures, codes and legal staff as the bases of its constitution, legitimation and evolution over time: their functioning and programing are technical-logical as much as their problems. Likewise, all that is not a technicallogical procedure, code and legal staff is delegitimized as arena, principle and subject of institutional legitimation and changing, by the technicality of the institutions, which at the same time autonomizes and closes them in relation to politics and social normativity.

A very important characteristic of contemporary politics appears from such understanding of the social systems or institutions. Now, as a set of impartial, neutral and formal procedures, codes and legal staff which have a technical-logical constitution, legitimation and managing, the institutions or social systems become non-normative and non-political instances, arenas, procedures and subjects. The fundamental institutional condition and characterization is its technicality, that is, the institution's depoliticized core and role, which leads to the non-political and non-normative institutional understanding, management and evolution. Of course, as said above, political praxis and social normativity can influence and even determine some aspects of the institution's structuration, grounding and evolution, but only indirectly, without substituting for the institution's technical-logical functioning and programming; the same way, social movements and citizen initiatives can influence and determine the institutions' legal staff in its proceduralism and action, but also only in an indirect way, because the institution's legal staff knows the technical-logical institutional functioning and programming, something that social movements and citizen initiatives do not know and cannot do. In this sense, the technical-logical constitution, legitimation and evolution of the social systems or institutions become a kind of scientism and instrumentalism, which is centralized and monopolized by a legal staff and institutional elites with a very political role and core regarding both the institution's definition and grounding and the legitimation and framing of the social vindications and political praxis from civil society's arena, practices and social-political subjects. Only the institutions' legal staff can understand, use and define from a scientific standpoint-from technical-logical procedures, codes and practices which are impartial, neutral, formal and very objective - the institutions' constitution, legitimation and evolution, because such technical-logical institutional understanding is not something that common people understand or that could be framed from normative-political principles, practices and subjects, because it is instrumental, logical and technical. Here, there is nothing political or normative that is proper to the multitude, but just the technical-logical functioning and programming (which is a question for specialists and elites based on a form of scientisminstitutions or social systems and scientism become very united, very interdependent, legitimizing one another).

Such technical-logical institutional constitution, legitimation and evolution means, in the first place, that each institution centralizes and monopolizes its specific social field, rendering it closed, self-referential and self-subsisting with regard to political praxis and social normativity, depoliticizing and naturalizing it. But a very political consequence is brought forth from this institutional technicality and depoliticized constitution: the fact that technical- 
logical institutions, their procedures and legal staff acquire a political role and core concerning the civil society's constitution, legitimation and action. Indeed, the technical-logical institution's understanding not only closes and autonomizes social systems or institutions in relation to civil society, by differentiating their constitution, legitimation and evolution regarding it, but also frame and control what civil society's principles, practices and political subjects can vindicate and act regarding the social systems, as they define how the arena, principles, practices and political subjects of civil society can act and influence the social systems' technical-logical functioning and programing. In other terms, technical-logical institutions not only require their autonomy and differentiation regarding the lifeworld; they also control and frame the lifeworld's vindications and praxis concerning themselves, so they submit the lifeworld's politicity and normative constitution to institutions' technical-logical, depoliticized functioning and programing. The technical-logical institutional understanding, therefore, both depoliticizes the institutions and hinders a political-normative praxis from civil society that can influence and frame social systems' pathologies.

A very important consequence arises from here, namely the contradiction and opposition between institutions, their technical-logical procedures and legal staff, and the social movements and citizen initiatives. This results from the division between social systems and lifeworld found in the theories of modernity proposed by Habermas and Giddens. They are actually aiming at its opposite, but the technical-logical constitution, legitimation and evolution of the social systems or institutions depoliticize them, closing and autonomizing them in relation to the political-normative constitution, legitimation and evolution of the lifeworld. Thus, a very strong barrier emerges between social systems and lifeworld, technical-logical procedures, codes and legal staff versus political-normative praxis, principles and subjects; a very strong barrier that can only be crossed, as HABERMAS and GIDDENS say, with an indirect political intervention into market and State (see HABERMAS, 2003a, p. 190; 2003b, p. 105-106; GIDDENS, 2000, p. 47-48). The technical-logical constitution, legitimation and management of the market and the State cannot be substituted with political praxis and social normativity; likewise, institutional elites and technicians cannot be changed by social movements and citizen initiatives. Such contradiction between technical-logical social systems and the normative-political lifeworld implies that social systems are basically depoliticized and non-normative structures and subjects which evolve over time from their technicality, from their overlapping with political praxis and social normativity, so the changing and legitimation of social systems are fundamentally technical-logical matters and procedures assumed by institutional elites and technicians. The social systems' self-justification can always appeal to such technicality, to such institutional non-political and non-normative constitution in order to avoid and minimize political praxis and social normativity as the basis of their politics and of the organization of institutions, closing and autonomizing them in relation to an inclusive and participative democracy.

Now, the first theoretical-political assumption to understand how Habermas and Giddens conceive of the political subjects of the process of Western modernization is the concept of social system or institution as a technical-logical structure and subject, as explained above. The second theoretical-political assumption to the definition of the social-political subjects of the process of Western modernization is the notion of complex society (see HABERMAS, 2003a, p. 17-20; GIDDENS, 2000, p. 142-149). This concept refers to five basic characteristics of contemporary societies, particularly Western democratic societies: (a) the fact that contemporary society is no longer a totality strongly imbricated in its parts and streamlined by macro-social-political subjects like social-political classes; (b) the societal division into many different and particularized social systems, each with their private logics and dynamics of 
functioning and programming; (c) systemic institutional self-differentiation, self-referentiality and self-subsistence as the basis of the process of Western modernization, correlatively to the normative-political constitution of the lifeworld; (d) the individualization of social-political subjects, which are no longer macro-social-political classes that can act normatively and politically in the name of all society; and (e) the nuclear core-role of the political-juridical institutions as centralizing and streamlining a notion of social normativity that is the common ground for the social, political and cultural life. Now, the process of Western modernization is marked by the consolidation of different and particularized social systems or institutions with a technical-logical constitution, legitimation and evolution. These social systems centralize and monopolize from the inside to the outside the structuration and grounding of their own social fields, closing them to other social fields and also to the lifeworld, which leads to the technicization, depoliticization and non-normative constitution of social systems. Thus, in speaking about the constitution, legitimation and evolution of social systems, the fact that their foundation and evolution is a matter and action performed from within the social systems, by their legal-staff, based on technical-logical procedures, codes and practices, has to be taken into account. The social system is its own lord, its own subject; it is its absolute path or arena, practice, principle and subject. No one from outside can intervene in it or change its technicallogical constitution, legitimation and evolution. That is the first and fundamental theoreticalpolitical point to understanding the process of Western modernization and acting on it.

The second fundamental fact in relation to a contemporary political theory of democracy is that a contemporary society grounded on this process of Western modernization-both cultural (secularization, individualism, universalism, democracy) and material (State's and market's systemic institutional self-differentiation, self-referentiality and self-subsistence)-is characterized by the individualization of social subjects, in the sense that they lose their class consciousness and belonging, becoming very individualized and particularized, so they cannot be integrated or directed as a mass unified from a single political-normative principle and as a very homogeneous group (see HABERMAS, 2003a, p. 20; 2003b, p. 24-25; GIDDENS, 2000, p. 47-48). That was a fact in the modern industrial society, which had a very pungent division into capitalist and working classes, but it is not found in current societies, according to Habermas and Giddens. Our societies are politically and culturally defined by the extreme individualization of social subjects: there are very particularized individuals and social-cultural groups; they cannot be understood from that Marxist division or from the concept of proletariat with labor as the basis of the theoretical-political approach. The social vindications and the political praxis are very plural and performed by individuals and social subjects that do not present the contraposition between capital and labor as the basis of their normative consciousness, political action and moral vindications. Because of that individualization of the social-political subjects, and because of the understanding of the process of Western modernization from the category of a technical-logical social system, the political democracy for a contemporary society cannot assume or be based on a direct intervention in these social systems by a form of macro-social-political subject. Such a subject does not exist anymore, which means that contemporary democratic politics acquire another core and role.

Indeed, according to Habermas and Giddens, politics is no longer the basis, the center of society as a whole. First, it is not the center of society since modern society is divided into different and particularized technical-logical social systems or institutions, so that each social system is the only arena, procedure and subject of its own constitution, legitimation and evolution, beyond political praxis and social normativity, becoming depoliticized. Political praxis has the conditions to streamline and frame the legitimation and evolution of social systems in order to protect and to promote the lifeworld's normative constitution and claims, 
but only indirectly (social rights, labor rights, ecological protection etc.), without substituting for the social systems' technical-logical procedures, principles and subjects. Therefore, politics is one social system alongside others, side by side and equally competing with other social systems. It is not the best or the most powerful one, but just one system like others. Each social system, including politics as an institution, has its own arenas, procedures, principles and subjects of functioning and programming, which are equally valid for their correlative institution-and only them. Secondly, politics is no longer the center of society because there are no longer macro-social-political classes which can assume a notion of social normativity and perform a direct political praxis in relation to social systems - in relation to the State and to capitalist market. Very particularized individuals and social-cultural groups, the moment they have no class consciousness and belonging, act in terms of a short-range political action. Here, the juridical-political institutions, organized in a systemic way correlative to a normative grounding, assume the center stage in terms of judgment of the political praxis and of the normative social claims (see HABERMAS, 2003b, p. 21-23).

Indeed, such double condition of the process of Western modernization in the contemporaneity leads to the centrality of institutionalism regarding civil society's normativepolitical arena, praxis and subjects. First, juridical-political institutions become the medium between social systems and lifeworld (see HABERMAS, 2003a, p. 25, p. 61-62, p. 82). They are actually a mixture of systemic organization and normative foundation. Their systemic organization means that their constitution, legitimation and evolution over time are determined from the internal impartial, neutral and formal proceduralism of juridical-political institutions, which is non-political and needs in many points a technical-logical staff acting from a nonpolitical point of view, as specialists or technicians - the legitimation of the juridical-political institutions is a matter for the institutions' internal proceduralism, codes and legal staff, which makes them highly self-referential, self-subsisting and autonomous regarding the civil society's arena, praxis and political subjects, according to Habermas's juridical-political proceduralism. In addition, juridical-political institutions are defined in their social-political action by the State's and the capitalist market's systemic self-referentiality, self-subsistence and autonomy regarding their own juridical-political procedure and framing, since their technical-logical constitution is particularized and opposed to political-juridical normative contents and foundations. So the juridical-political institutions cannot substitute for or directly intervene in the bureaucratic power and money. At the same time, juridical-political institutions, the moment they become the medium between social systems and lifeworld, must stop civil society's direct political praxis of assuming political-normative centrality in terms of the institutions' framing and changing, by the fact that it is the very juridical-political institutions that constitute themselves as the arena, the procedure and the subjects of institutional transformation. In this way, juridical-political institutions, based on an impartial, neutral and formal organization, proceduralism and legal staff, are not only prevented from intervening in technical-logical social systems, substituting their technical-logical principles and subjects with civil society's normative-political principles and subjects; they must also hinder the political subjects of civil society to substitute the very institutions, their impartial and neutral internal proceduralism and legal staff concerning the arena, the procedures and the political subjects of social transformation. Juridical-political institutions become the very arena, proceduralism and subject both of institutional and of societal constitution, legitimation and evolution, beyond civil society's social movements and citizen initiatives. The political praxis of social movements and citizen initiatives acquire a very peripheral, secondary role and core regarding the very juridical-political institutions. Furthermore, side by side with the juridical-political institutions' centralization of the arena, procedures and subjects of social evolution, the technical-logical 
institutions depoliticize the bureaucratic power and mainly money as social fields normatively and politically constituted, hindering a direct normative criticism and political praxis against them.

The powerlessness and even the conservatism of juridical-political institutions appear from this condition found in Habermas's and Giddens's systemic understanding of both the State and the capitalist market, and of the juridical-political institutions' structuration, legitimation and evolution. If, on the one hand, the juridical-political institutions are based on a notion of social normativity which gives them the ability to protect and foment the lifeworld in relation to the evolution of social systems, minimizing their technical-logical totalizing process into the lifeworld; on the other hand, these institutions are incapable of performing a more acute and decisive normative-political intervention into the bureaucratic power and money, very imbricated nowadays, by their technical-logical constitution and legitimation which depoliticize them. Moreover, the juridical-political institutions' impartial, neutral and formal organization and action prevent their recognition as political institutions, arena, procedures and subjects, depoliticizing them as well, as occurs with bureaucratic power and money. So, how can impartial, neutral and formal juridical-political institutions become democratic and, at the same time, perform a normative-political change in the market and the State? This is impossible, of course-or, at least, it is a very difficult enterprise. In both situations, juridical-political institutions close themselves to a direct democratic political praxis, and cannot act in the name of society into the bureaucratic power and market dynamics.

That is the reason why, in Habermas's juridical-political procedural paradigm and in Giddens's theory of modernity, the juridical-political institutions, in the moment that they become the medium between social systems and lifeworld, centralize and monopolize the arena, the procedures, the codes and the legal subject of the societal justification, at the same time that the State and the capitalist market are autonomized regarding both civil society's normativepolitical praxis and the juridical-political institutions' function of medium in favor of the lifeworld. Juridical-political institutions, despite the fact that they are based on social normativity, having to protect the lifeworld against social systems, cannot substitute for the social systems' private, self-referential, technical-logical codes of power. Allied to that, the individualization of social subjects also prevents civil society's normative-political centrality in terms of legitimation of a direct democratic political praxis based on social normativity which can face, frame and change the social systems' self-referentiality and self-subsistence, the social systems' technical-logical constitution, legitimation and evolution. These individualized and particularized social subjects cannot assume a macro normative-political praxis against the institutions or replace the institutions in the name of all society, or even substitute for the social systems' internal functioning and programming with the civil society as the arena, the praxis and the subject of institutional constitution. In this case, the Habermasian notion of citizenship without subject as the basis of the juridical-political proceduralism means that the political praxis cannot be centralized and monopolized by macro-social-political classes-which no longer exist, according to them. As a consequence, the very juridical-political institutions-and only they-assume such ability to act in the name of society as a whole, centralizing and monopolizing social normativity in the name of all society and becoming, therefore, the very arena, proceduralism and subject of social evolution. As said above, individualized and particularized social subjects can act politically concerning the institutions and social systems, but not only can they not substitute for the institutions, the institutions' self-referentiality and self-subsistence, their technical-logical organization; they cannot substitute for the juridicalpolitical institutions' formal, impartial and neutral procedures, praxis and actors as well (see HABERMAS, 2003b, p. 25, p. 104-106). Social movements and citizen initiatives, therefore, 
have a secondary role, while social systems are depoliticized, and juridical-political institutions become overlapped with civil society, social movements and social struggles, so they become the arena, the proceduralism and the judge of civil society, of political praxis: from now on, a democratic political praxis is an institutional formal, impartial and neutral political praxis, as the social-political subjects are the institutions' legal staff, the same as democratic political arena and procedures become the institutional sphere and proceduralism. And the institutions' arena, procedure and subject are technical-logical because of their impartiality, neutrality and formality regarding the politicity-carnality of the social-political subjects and their struggles for hegemony. Overlapped with civil society's social-political classes and struggles, formal, impartial and neutral institutions lose their politicity-carnality, becoming self-referential and self-subsisting structures and subjects, acquiring a depoliticized structuration and legitimation, which are basically technical-logical practices and procedures and subjects.

\section{Recovering a Normative-Political Notion of Institution and of Social Subject: Some Conclusions}

Where is the social subject? Or better: who is the political subject of social evolution? How is it constituted? How does it act? These questions were answered above from the point of view of Jürgen Habermas's and Anthony Giddens's theories of modernity. Their understanding of the process of Western modernization as based correlatively on the division of European modernity between technical-logical institutions or social systems and the lifeworld leads to the notion that each social system centralizes and monopolizes the constitution, the legitimation and the evolution of its own field, closing, technicizing and depoliticizing itself, so that a direct democratic political praxis based on a binding notion of social normativity is delegitimized as the basis for framing, problematizing and changing the social systems. Technical-logical institutions become the very subject, arena, procedure and criteria of their own grounding and action over time. The fundamental characteristic and consequence of such technical-logical understanding of social systems is not only their depoliticization and non-normative constitution, but also their overlapping and even contraposition to nowadays political-normative life, to social forces and social struggles, as well as to social needs. Indeed, technical-logical institutions appear as depoliticized, impartial, neutral and formal sets of procedures, codes and legal staff which are determined by and which obey only to technical-logical commands, programming, actions and subjects. Here, institutions or social systems lose their politicity-carnality in the sense that they are conceived of as strongly independent of the social-political classes and of their struggles with each other for political-normative hegemony. Institutions or social systems with no politicity and carnality, with no political-normative foundations, contents and subjects are the result of a technical-logical understanding of the constitution of modern social systems, as bureaucratic power and money. Consequently, bureaucratic power and money, as technicallogical spheres, subjects and powers, are a matter of technocracy. Technocracy is not something political, but fundamentally technical-logical; its politicity is made possible by its technicality, that is, by the fact that technicians do understand the functioning and programing of social systems, acquiring every right to legitimize and streamline them over time, beyond politics and social normativity.

There is no technicality functioning as the basis of the grounding and streamlining of social systems or institutions. Institutions are not a set of impartial, neutral and formal procedures, codes and legal staff, since they are not overlapped with and opposed to political praxis, becoming self-subsistent, self-referential and autonomous structures, codes and subjects. Likewise, their management is not a technical-logical procedure objectively and scientifically coordinated, centralized and monopolized by technicians and elites. Institutions or social 
systems are fundamentally political structures and subjects defined by social-political struggles for hegemony between opposed social-political classes. Such politicity-carnality is the normative-epistemological basis for theoretical analysis and political praxis. If such normativeepistemological basis is ignored or denied, institutions become depoliticized, at the same time as the theoretical analysis and political praxis are delegitimized as the fundamental normativepolitical core of societal and institutional constitution, grounding and evolution. By the negation of the institutions' or social systems' politicity-carnality, technical-logical analysis and political technocracy acquire complete legitimacy to centralize and monopolize the institutional structuration, grounding and dynamics beyond a direct democratic political praxis coordinated by social-political classes from social struggles which criticize, frame and reject the institutions' self-referentiality, self-subsistence and autonomy. In other terms, it is the emphasis on the politicity-carnality of the institutions that allows their politicization and normative constitution, avoiding their technical-logical constitution and legitimation, politicizing them as part of the normative-political social world and as a result of social struggles. Here, institutions are not independent of and overlapped with the lifeworld, but actually a result of the lifeworld's normative-political dynamics, subjects and struggles. Here, situated within the lifeworld's normative-political constitution, subjects and struggles, institutions are in no way technicallogical, but actually very political instances.

The theoretical-political standpoint proposed in this article for a critical social theory that could serve as epistemological-normative basis for a radical democratic political praxis assumed and streamlined by social movements and citizen initiatives in relation to the social systems or institutions is to refuse any technical-logical understanding of these social systems or institutions in order to conceive of them basically and purely as normative-political institutions, procedures and subjects, situating them within civil society and as the result of the socialpolitical struggles for hegemony between opposed social-political classes. Firstly, as said above, a technical-logical understanding of social systems depoliticizes them, removing them of their politicity-carnality by technicizing them and rendering them self-referential, self-subsisting and autonomous structures, procedures and subjects regarding political praxis and social normativity, concerning social movements and citizen initiatives. The institutional technicallogical understanding as the basis of political action regarding the social systems leads to technocracy as a fundamental parameter of institutional constitution, legitimation and evolution. Secondly, Habermas's and Giddens's theoretical-political strategy-which consists of the division of Western modernization into technical-logical social systems and the normativepolitical lifeworld - is not sufficient to recover and to renew a democratic political praxis and a critical social analysis (as imbricated points) for the contemporary context and crisis of Western modernization and especially to face the hegemonic political-economic conservatism concerning the understanding and the resolution of the current social-economic crisis (see PIKETTY, 2014; RANCIÈRE, 2014; HONNETH, 2003). This strategy employed by Habermas and Giddens does not work due to the fact that it continues to assume a technical-logical understanding of social systems, even if situating them into the normative-political lifeworld.

Indeed, what kind of mutual contact and influence is presupposed and required by a technical-logical structure, procedure and subject situated within the normative-political lifeworld? What kind of political-normative intervention is enabled from the correlation between technical-logical social systems and the normative-political lifeworld? In relation to this point, Habermas's and Giddens's theoretical-political proposal is very clear: only an indirect political intervention in the market and the bureaucratic power is valid and possible by social movements and citizen initiatives, because such forms of power (technocracy) have a technical-logical structuration, functioning and programming, becoming also and

DANNER, Leno Francisco; DANNER, Fernando. Political Praxis, Social Analysis and Western Modernization: A Theoretical-Political Route for Critical Social Theory. Griot : Revista de Filosofia, Amargosa-BA, v.20, n.2, p.154-173, junho, 2020. 
fundamentally a matter for specialists, technicians and institutional elites: here, common people can influence and act politically, but the final decision is a question and a praxis for institutional subjects from institutional dynamics, procedures and codes. So, there is a much undefined medium between social systems and the lifeworld that cannot be occupied, completed for popular political praxis and social normativity. After all, how much of the political praxis is valid and possible by civil society in relation to the social systems? On the other hand, how and to what extent can the social systems accept political-normative praxis, contents and subjects without being hindered in their self-referentiality, self-subsistence and autonomy regarding exactly democratic politics and social normativity? And, of course, to what extent do the technical-logical structure, procedure, codes and legal staff allow an effective cooperation and mediation with the civil society's normative-political use values, with the praxis of social movements and citizen initiatives? To what extent can political praxis and social normativity determine the social systems' technical-logical constitution, legitimation and evolution?

The same situation occurs within the ambit of juridical-political institutions. The centrality of social systems regarding their own constitution, legitimation and evolution, their technicality and depoliticized self-understanding are the first problematic theoretical assumptions to hinder and delegitimize a direct political praxis oriented toward their framing and changing, as the technical-logical understanding of social systems prevents their own politicization. Likewise, Habermas's and Giddens's placing of juridical-political institutions as medium and subject between social systems and the lifeworld is another-and maybe a more harmful-theoretical assumption to ground both a critical social theory and a democratic political praxis to understanding, framing and changing the contemporary process of Western modernization. Indeed, juridical-political institutions are based on a systemic structuration, insofar as they are a set of impartial, neutral and formal structures, procedures, codes and legal staff which stabilizes, streamlines and legitimizes themselves from the inside to the outside, becoming also self-referential and self-subsisting regarding the politicity-carnality of the socialpolitical subjects and the social-political struggles nowadays. The juridical-political institutions, due to such formality, impartiality and neutrality, are not actually political, and this is the reason why they centralize and streamline social normativity, becoming the judge both of the correlations between social systems and the lifeworld and of the social vindications and the praxis of political subjects. By doing that, juridical-political institutions become the very arena, procedures, codes and political subject of social evolution and institutional constitution, that is, they become depoliticized arenas, procedures, codes and subjects of the societal and institutional constitution. In this situation, juridical-political institutions cannot promote a radical political praxis by social movements and citizen initiatives in relation to the technicallogical social systems, but they also cannot protect and impose the civil society's normativepolitical legitimation, claims and praxis in relation to the technicality of the social systems, due to a double factor: juridical-political institutions are not really political subjects, but systemic ones; and the social systems are technical-logical structures which only admit indirect political intervention (whatever that means!) in the market and the bureaucratic State.

The undefined medium and contact zone between social systems and the lifeworld favor the social systems' closure and technicality, their depoliticization, as they hinder a direct democratic political praxis within civil society in relation to the social systems themselves. Who defines what, how much and in which way the correlation between technical-logical social systems and the normative-political lifeworld can be grounded and performed? Habermas and Giddens have a huge difficulty to answer that question, because systemic logics and normativepolitical praxis are very opposed to one another, and they establish structures, actions, codes and subjects that are completely different in terms of institutional legitimation and of mutual 
contact. So, systemic institutions can always appeal to their technical-logical constitution and grounding, to their depoliticized functioning and programming, as a form of hindering the political-normative praxis of democracy. What does link social systems and the lifeworld? If it is the lifeworld, then social systems are not technical-logical, but normative-political. However, the technical-logical organization and functioning of the social systems both depoliticize them and lead them to overlap and oppose the normative-political societal structuration and evolution. Likewise, such a technical-logical understanding of the institutions leads to the centrality of their internal proceduralism and legal staff regarding their evolution and also in relation to the societal evolution, by erasing the fact that both institutions and society's evolution are performed and defined by the social-political struggles between conflictive social classes. Systemic institutions are not just unpolitical structures; they also erase the politicity of the social-political classes, as of the social-political struggles, correlatively avoiding and hindering institutional politicization and a direct democratic political praxis which politicizes these systemic institutions.

In this sense, the placement of juridical-political institutions as a medium between systems and the lifeworld does not resolve such an undefined and also depoliticized point of contact between systems and lifeworld. On the contrary, this radicalizes the indefiniteness and the depoliticization both of this correlation between social systems and lifeworld and mainly of this very medium constituted by the Rule of Law and of the parliaments-which must apply the Constitution both to social systems and to civil society. On the one hand, technical-logical social systems cannot be intervened in from outside by a direct political praxis based on social normativity, as their internal technical-logical procedures, codes and legal staff cannot be changed by normative-political praxis, principles and subjects. On the other hand, the juridicalpolitical institutions themselves, in the moment they assume the impartial, neutral and formal proceduralism, codes and legal staff, become very technical and depoliticized, because they not only close themselves to the politicity-carnality of social subjects and political clashes, but also become institutionalist structures and subjects, consolidating an overlapping of civil society, their social-political classes and struggles. As a consequence, the juridical-political institutions, on one side, cannot represent the social-political classes nor foment their struggles against the institutions (juridical-political institutions are a social system, too!), because of their formality, impartiality and neutrality, which make them very conservative structures and subjects; on the other side, they must also protect and foment the institutions' or social systems' selfreferentiality and self-subsistence, that is, they must guarantee the technical-logical constitution, legitimation and evolution of social systems, which is a right given to them by Western modernization. Therefore, juridical-political institutions refuse the politicity of social subjects and of their struggles for hegemony, refusing, as a consequence, that these socialpolitical subjects and classes define institutional configuration, understanding and functioning. Thus, they understand that the institutional and societal legitimation and evolution is defined from the institutions' self-movement and self-legitimation, as if institutions, as a set of impartial, neutral and formal procedures, codes and legal staff, were independent of and overlapped with the social-political classes and their struggles. That means, on the other hand, that institutions centralize, legitimize and streamline their own constitution and also the societal dynamics over time, leading to the depoliticization of the institutions and to the institutional refusal of the politicity of social-political subjects and their struggles for hegemony. As said above, juridical-political institutions, in the moment that they become the medium between systems and the lifeworld, acquire a depoliticized and formal constitution, legitimation and evolution, hindering the politicity-carnality of the social-political classes and their struggles, autonomizing the social systems, legitimizing their self-subsistence, self- 
referentiality and closure regarding political praxis and social normativity. Juridical-political institutions only work from and by institutionalism; they only live from and by it, an institutionalism with no politicity-carnality, based on a very false formalist, impartial and neutral proceduralism that acquires both a technical-logical legitimation and management performed and centralized by institutional elites and technicians.

Now, only a normative-political understanding of the institutions can enable a radical democratic political praxis in relation to the social systems, as a counterpoint to their technicality and depoliticized constitution - a radical because direct political praxis is based on the theoretical starting point of the complete politicity-carnality of social systems, socialpolitical classes and social-political struggles. For the social movements and citizen initiatives, that is a crucial question: they must always refuse any technicization of the social systems or institutions as much as that of the juridical-political institutions in favor of a very fundamental politicity-carnality. As a consequence, the permanent social struggles involving social movements and citizen initiatives must assume a direct intervention in the technical-logical social systems in order to unveil and face the most dangerous problem of contemporary politics, that is, the deep imbrication between strong institutionalism (social systems' technical-logical constitution, depoliticization, self-referentiality and self-subsistence), economic oligarchies and political parties based on the systemic understanding of the institutional and societal constitution and legitimation. Here, only the radical and complete politicization of all social systems and institutions, of all societal dynamics can provide the theoretical-political route for a critical social theory that correlatively intends to perform a critical analysis of the social systems and the institutions and legitimize and streamline emancipatory social-political subjects who can assume and perform a direct political praxis against political-economic conservatism based on the systemic theory. All is politics and political-that is the theoreticalpolitical basis for a critical social theory which can politically frame the process of Western modernization for a democratic political praxis performed by very politicized social classes that establish social struggles as the core and the role from which the institutional and societal constitution and legitimation are problematized and defined over time, as permanent and political contraposition to conservatism and to systemic logic in politics. 


\section{References}

FORST, Rainer. Contextos da justiça: filosofia política para além de liberalismo e comunitarismo. São Paulo: Boitempo, 2010.

FROMM, Erich. Marx y su concepto de hombre. México: Fóndo de Cultura Económica, 1970.

FROMM, Erich. Beyond the chains of illusion: my encounter with Marx and Freud. New York: Continuum Books, 2009.

GIDDENS, Anthony. Para além da esquerda e da direita: o futuro da política radical. São Paulo: Editora da UNESP, 1996.

GIDDENS, Anthony. "A vida em uma sociedade pós-tradicional". In: GIDDENS, Anthony; BECK, Ulrich; LASH, Scott. Modernização reflexiva: política, tradição e estética na ordem social contemporánea. São Paulo: UNESP, 1997.

GIDDENS, Anthony. A terceira via: reflexões sobre o impasse da social-democracia. Rio de Janeiro: Record, 2000.

GIDDENS, Anthony. A terceira via e seus críticos. Rio de Janeiro: Record, 2001.

HABERMAS, Jürgen. Teoria da ação comunicativa (Vol. I): racionalidade da ação e racionalização social. São Paulo: Martins Fontes, 2012a.

HABERMAS, Jürgen. Teoria da ação comunicativa (Vol. II): sobre a crítica da razão funcionalista. São Paulo: Martins Fontes, 2012b.

HABERMAS, Jürgen. Direito e democracia: entre facticidade e validade (Vol. I). Rio de Janeiro: Tempo Brasileiro, 2003a.

HABERNMAS, Jürgen. Direito e democracia: entre facticidade e validade (Vol. II). Rio de Janeiro: Tempo Brasileiro, 2003b.

HABERMAS, Jürgen. O Discurso filosófico da modernidade: doze lições. São Paulo: Martins Fontes, 2002a.

HABERMAS, Jürgen. $A$ inclusão do outro: estudos de teoria política. São Paulo: Loyola, 2002b.

HABERMAS, Jürgen. Ensayos políticos. Barcelona: Ediciones Península, 1997.

HONNETH, Axel. Luta por reconhecimento: a gramática moral dos conflitos sociais. São Paulo: Editora 34, 2003.

HONNETH, Axel. Reificación: un estudio en la teoría del reconocimiento. Buenos Aires: Katz, 2007.

LUHMANN, Niklas. La sociedad de la sociedad. México: Herder, 2006.

MARX, Karl. Manuscritos econômico-filosóficos. Tradução de Alex Marins. São Paulo: Martins Claret, 2013.

MARX, Karl; ENGELS, Friedrich. A ideologia alemã. Tradução de Luis Claudio de Castro e Costa. São Paulo: Martins Fontes, 2008.

PARSONS, Talcott. A estrutura da ação social (vol. I). Rio de Janeiro: Editora Vozes, 2010a.

PARSONS, Talcott. A estrutura da ação social (vol. II). Rio de Janeiro: Editora Vozes, 2010b.

PIKETTY, Thomas. (2014), O capital no século XXI. Rio de Janeiro: Intrínseca.

RANCIÈRE, Jacques. $O$ ódio à democracia. Tradução de Mariana Echalar. São Paulo: Boitempo, 2014.

RAWLS, John. Justiça como equidade: uma reformulação. São Paulo: Martins Fontes, 2003.

WEBER, MaxEnsayos sobre sociología de la religión (T. I). Madrid: Taurus, 1984.

Contribuição dos(as) autores(as): Leno Francisco Danner e Fernando Danner participaram da pesquisa, discussão e redação do artigo. Ambos aceitaram e aprovaram a versão final do texto.

Autor(a) para correspondência: Leno Francisco Danner, BR 364, KM 9.5, Zona Rural, 76801-059, Porto Velho RO, Brasil. leno_danner@yahoo.com.br 